(C) В.І. Русин, Я.М. Попович, В.В. Корсак, С.О. Бойко

УДК 616.146-005.6:611.14.068

\title{
Кровоплин при тромбозах у кавальному венозному колекторі
}

В.І. Русин, Я.М. Попович, В.В. Корсак, С.О. Бойко

Ужгородський начіональний університет, медичний факультет, кафедра хірургічних хвороб, Ужгород

\section{Реферат}

У роботі наведено аналіз результатів обстеження 121 хворого з тромбозами у кавальному венозному сегменті. Включення в комплекс клініко-інструментального обстеження пацієнтів (ультразвукові дуплексне сканування та доплерографія, рентгеноконтрастна флебографія, спіральна комп'ютерна томографія з внутрішньовенним контрастуванням) радіоізотопної флебосцинтиграфії дозволило оцінити анатомічні передумови компенсації колатерального венозного кровоплину при тромбозах у кавальному колекторі. Вивчення шляхів компенсації колатерального кровоплину при тромбозах у кавальному венозному колекторі дозволяє диференційовано підходити до вибору методу профілактики тромбоемболії легеневої артерії, обгрунтувати покази до хірургічного лікування тромбозів глибоких вен у системі нижньої порожнистої вени та запобігти виникненню хронічної венозної недостатності.

Ключові слова: тромбоз глибоких вен, кавальний венозний колектор, колатералі, венозна магістраль.

Blood flow in thrombosis in the caval venous collector

V.I. Rusyn, Y.M. Popovych, V.V. Korsak, S.O. Boyko

Uzhhorod National University, School of Medicine, Department of surgical diseases, Uzhhorod

\section{Abstract}

The paper presents an analysis of the survey results 121 patients with venous thrombosis of caval segment. Inclusion in complex clinical and instrumental examination of patients (ultrasonic duplex scanning and doppler, phlebography, multislice computed tomography with intravenous contrast) of the radionuclide scintigraphy possible to assess anatomical prerequisites compensation collateral venous flow in caval thrombosis collector. The study of the anatomical features of compensation collateral flow caval thrombosis in the venous reservoir allows a differentiated approach to the selection method of prevention of pulmonary embolism, ground indications for surgical treatment of deep vein thrombosis in the inferior vena cava system and prevent chronic venous insufficiency.

Key words: deep vein thrombosis, caval venous collector, collaterals, venous magistral.

Вступ. Лікуванню тромбозів глибоких вен (ТГВ) у системі нижньої порожнистої вени (НПВ) присвячена велика кількість робіт, що торкаються причин виникнення, механізмів розвитку, клінічних проявів, методів діагностики, показів та протипоказів до різноманітних видів терапії. Лікування тромбозів у системі НПВ досі не стандартизовано, відсутній єдиний погляд як на різні схеми консервативної терапії (терапія низькомолекулярними гепаринами, системний i регіонарний тромболізис), так і на численні хірургічні методи лікування (плікація НПВ, тромбектомія на тлі прискореного кровотоку або без нього, імплантація кава-фільтрів та ін.) [1, 2].

Показання та протипоказання до них часто суперечать один одному, а результати лікування залишаються незадовільними. Тромбоемболію легеневої артерії (ТЕЛА), як і раніше, вважають однією $з$ головних причин летальності в хірургічних стаціонарах, а кількість хворих з важкими формами хронічної венозної недостатності (XBH) неухильно зростає $[3,4,5]$.

Відсутні чіткі протоколи профілактики венозного тромбоемболізму, навіть при проведенні фармакологічної профілактики у 45\% пацієнтів протипоказане використання низькомолекулярних гепаринів, а механічну профілактику, зокрема носіння еластичного трикотажу, призначають лише кожному третьому пацієнту [7].
У той же час чим вище локалізується верхня межа тромботичної оклюзії, тим вище ризик виникнення ТЕЛА з летальним наслідком. Так, наприклад, ризик ТЕЛА при тромботичній оклюзї̈ клубових вен, за відсутності антикоагуляційної терапії, знаходиться у межах 70\%, а смертність досягати $5 \%$ щодоби $[6,8]$.

Однією з причин відсутності чіткого підходу до лікування даної серйозної патології є відсутність уяви про анатомічні особливості венозної системи нижньої порожнистої вени, особливо про широкі компенсаторні можливості колатерального венозного кровоплину при тромбозах у кавальному колекторі. Жоден з авторів не надає відповідної уваги питанню вивчення анатомічних передумов компенсації венозного кровоплину при тромбозах глибоких вен в системі нижньої порожнистої вени.

Мета дослідження. Вивчити анатомічні передумови компенсації венозного кровоплину при тромбозах у кавальному венозному колекторі.

Матеріали та методи. У роботі проаналізовано результати обстеження та лікування 121 хворого $з$ тромбозами нижньої порожнистої вени, яких проліковано у відділенні хірургії магістральних судин та урології Закарпатської обласної клінічної лікарні ім. А. Новака протягом 2008 - 2018 років. Вік хворих становив від 31 до 76 років, середній вік $-52 \pm 1,8$ року. 
Для обстеження хворих застосували лабораторні методи дослідження, а також інструментальні: ультразвукову доплерографію, ультразвукове дуплексне сканування («ULTIMA PRO-30, z.one Ultra», ZONARE Medical Systems Inc., СШA); рентгеноконтрастну флебографію (DSA, Integris-2000, Philips) та мультиспіральну комп'ютерну томографію 3 внутрішньовенним контрастуванням (Somatom CRX «Siemens», Німеччина, 1994). Paдіоізотопна флебосцинтиграфія проводилася на емісійному комп'ютерному томографі «Тамара» (ГКС-301Т) виробництва ГПФ СКТБ «Оризон» Україна, НИО ЩГК НТК «Інститут монокристалів» НАН України, СП «Амкрис-Эйч».

Результати досліджень та їх обговорення. Золотим стандартом діагностики пацієнтів 3 ТГВ системи нижньої порожнистої вени (НПВ) залишається ультразвукова діагностика. Всім пацієнтам як скринінг виконували ультразвукові доплерографію та дуплексне сканування.

Проведення чіткої ультразвукової діагностики ТГВ у ілеофеморальній позиції досить часто утруднюються вираженим метеоризмом (непідготовленість пацієнта до обстеження), підвищеною вгодованістю, конгломератами збільшених лімфовузлів, запальними та злоякісними новоутворами малого тазу. Крім того, певні труднощі викликає ультразвукова візуалізація верхівки тромботичної оклюзії у клубових та нижній порожнистій венах, характер тромботичних мас та наявність їх флотації.

Із метою уточнення локалізації верхівки та наявності флотації тромботичних мас, використовували мультиспіральну комп'ютерну томографію 3 внутрішньовенним контрастуванням. Як контраст використовували ультравіст в кількості $100-200$ мл на одне обстеження. У 16 (3,5\%) пацієнтів при неможливості виконати мультиспіральну комп'ютерну томографію виконували рентгеноконтрастну флебографію.

Для оцінки функціонального венозного кровоплину при ТГВ використовували радіоізотопну флебосцинтиграфію з Тс-99м-пертехнетат. Кровоплин досліджували, головним чином, у вертикальному положенні, оскільки саме ці умови найбільш повно відтворюють фізіологію кровообігу у людини. Виключення складають пацієнти, у яких за даними У3-ангіосканування був достовірно діагностований флотуючий характер тромбу. Внаслідок високого ризику тромбоемболії дослідження виконували в горизонтальному положенні пацієнта.

Грунтуючись на даних, які отримані в результаті використання додаткових методів обстеження (ультразвукові, рентгенконтрастні та радіоізотопні), відзначили, що у формуванні кожного венозного сегменту беруть участь такі анатомічні структури:

1) «приносна магістраль»: загальні клубові вени;
2) колатералі або «природний шунт»: непарна та напівнепарна вени, поперекові вени та їх венозні сплетення, міжхребцеві та нижні діафрагмальні вени, печінкові вени, венозні сплетення малого тазу та гілки внутрішньої клубової вени тощо;

3) «виносна магістраль» - нижня порожниста вена;

4) венозний колектор, який формується в місці злиття магістралей та колатералей.

Найбільше значення в порушенні відтоку має венозний колектор. У колектор завжди впадає приносна магістраль та декілька колатералей, здатних частково компенсувати непрохідність приносної магістралі, а виходить одна виносна магістраль, яка є приносною для вищерозміщеного сегмента.

Кожен колектор має обхідний шлях (колатералі) - природний шунт, від функціональної можливості якого залежить ступінь порушення відтоку при оклюзії колектора.

Для кращої уяви про симптоми венозної обструкції нижньої порожнистої вени, необхідна чітка уява про магістральний та колатеральний венозний кровоплин у системі нижньої порожнистої вени. При тромбозі глибоких вен у системі нижньої порожнистої вени в першу чергу страждає магістральний венозний кровоплин. При цьому компенсація венозного відтоку від нижньої кінцівки відбувається завдяки колатеральному кровоплину (рис. 1).

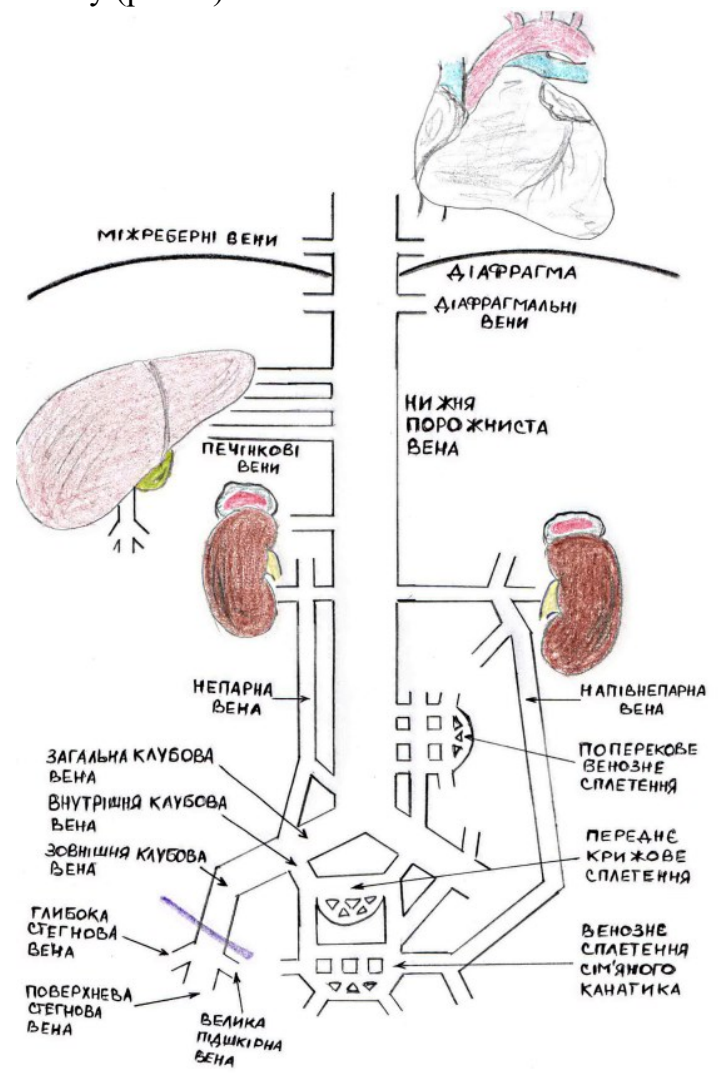

Рис. 1. Схема колатерального венозного відтоку у кавальному колекторі 
Основними колатеральними шляхами компенсації венозного кровоплину у системі нижньої порожнистої вени $є$ басейн глибокої стегнової та внутрішньої клубової вен, велика та мала підшкірні вени, венозні сплетення малого тазу та поперекової ділянки. Незважаючи на це, можливості компенсації магістрального та колатерального венозного кровоплину при тромбозах глибоких вен у системі нижньої порожнистої вени досить обмежені.

При тромботичній оклюзії нижньої порожнистої вени слід диференціювати рівень проксимальної та дистальної меж венозної обструкції, локалізацію та характер тромботичних мас, характер верхівки тромботичних мас. За характером проксимальної частини тромботичний процес поділяють таким чином: оклюзивний, фрагментарний, пристінковий та флотуючий. Найбільш небезпечний в плані тромбоемболічних ускладнень є флотуючий характер верхівки тромботичних мас. За рівнем проксимальної межі венозної обструкції тромбози нижньої порожнистої вени слід умовно поділити на такі сегменти:

- інфраренальний;

- інтраренальний;

- супраренальний;

- гепатальний;

- інфрадіафрагмальний;

- супрадіафрагмальний;

- інтракардіальний.

Залежно від ураження певного сегменту нижньої порожнистої вени переважає та чи інша симптоматика. При локалізації верхівки венозної обструкції в інфраренальному відділі нижньої порожнистої вени у пацієнтів, як правило, діагностують протяжне тромботичне ураження стегновоклубового венозного сегменту. При цьому, в патологічний процес, крім кавального венозного колектору, залучається клубовий колектор. На перший план виходять симптоми тромбозу глибоких вен нижніх кінцівок: виражений набряк, біль та ціаноз шкіри нижньої кінцівки. Компенсація венозного відтоку відбувається за рахунок гілок системи внутрішньої клубової вени, венозних сплетень сечового міхура та прямої кишки, крижового венозного сплетення, середньої крижової вени, які збирають венозну кров від ураженої кінцівки та дренуються в поперекові, міжхребцеві та ниркові вени, непарну та напівнепарну вени, поперекові венозні сплетення, які в свою чергу впадають в нижню порожнисту вену вище рівня тромботичної оклюзії.

При тромботичній оклюзії інтраренального та супраренального відділу нижньої порожнистої вени на перший план виступає симптоматика ураження внутрішніх органів, зокрема нирок. Найчастіше це спостерігається при злоякісних пухлинах нирок. При цьому, окремої уваги заслуговують пухлинні тромбози нижньої порожнистої вени при раку нирки. 3 боку нижніх кінцівок, як правило, клінічна симптоматика відсутня.

При раку правої нирки колатеральний венозний кровоплин забезпечується за рахунок дрібних капсулярних, надниркових, нижньодіафрагмальних і сечовидних вен, які часто не мають прямого сполучення 3 правою нирковою веною (рис. 2). Даний венозний колектор при блокаді нижньої порожнистої вени переважно дренується в басейн напівнепарної вени і спрямовується вздовж хребта вгору до іiі впадіння в систему брахіоцефальних гілок. У басейн цієї вени впадають чисельні стовбури, пов'язані 3 ретрокавальною системою на рівні каудального відділу нижньої порожнистої вени. Колатеральні гілки розширюються, рівень тиску в них посилюється, вони стають напруженими і небезпека кровотечі при їх пораненні під час операції значно зростає. Окрім цих гілок, у напівнепарну вену впадають також розширені міжхребцеві гілки, що мають горизонтальний хід.

Дещо інакше відбувається колатеральний венозний відтік з лівої нирки. Перш за все, в нормальних умовах відтік венозної крові від лівої нирки відбувається по сім'яній вені, на частку якої припадає до 40\% відтоку крові. Вона впадає в ліву загальну клубову вену, звідки через комунікантні вени поступає в систему непарної вени, яка доставляє кров безпосередньо у верхню порожнисту вену. Широкий відтік венозної крові може виконуватися через нижню діафрагмальну вену, кровоплин якої спрямовується в інфрадіафрагмальний відділ нижньої порожнистої вени. Окрім того, як і справа, в колатеральному венозному відтоці бере участь система міжхребцевих, капсулярних і сечовідних вен (рис. 3).

Більш виражений венозний колатеральний кровоплин з лівої нирки пояснює і той факт, що при тромбозах нижньої порожнистої вени, зумовлених раком лівої нирки, у чоловіків майже завжди виявляють варикоцеле. Окрім того, під час каваграфії завжди відзначають більш виражену венозну колатеральну сітку зліва.

При тромботичній оклюзії гепатального та інфрадіафрагмального відділів нижньої порожнистої вени, із захопленням в процес печінкових вен, на перший план виступає клінічна картина, характерна для синдрому Бадда-Кіарі: гепатомегалія, диспептичні явища, розширення вен передньої черевної стінки, симптоми портальної гіпертензії. Компенсація колатерального венозного кровоплину відбувається 3 використанням поперекових та міжхребцевих вен, поперекових венозних сплетень, непарної та напівнепарної вен, нижніх та верхніх діафрагмальних вен, портокавальних анастомозів. 

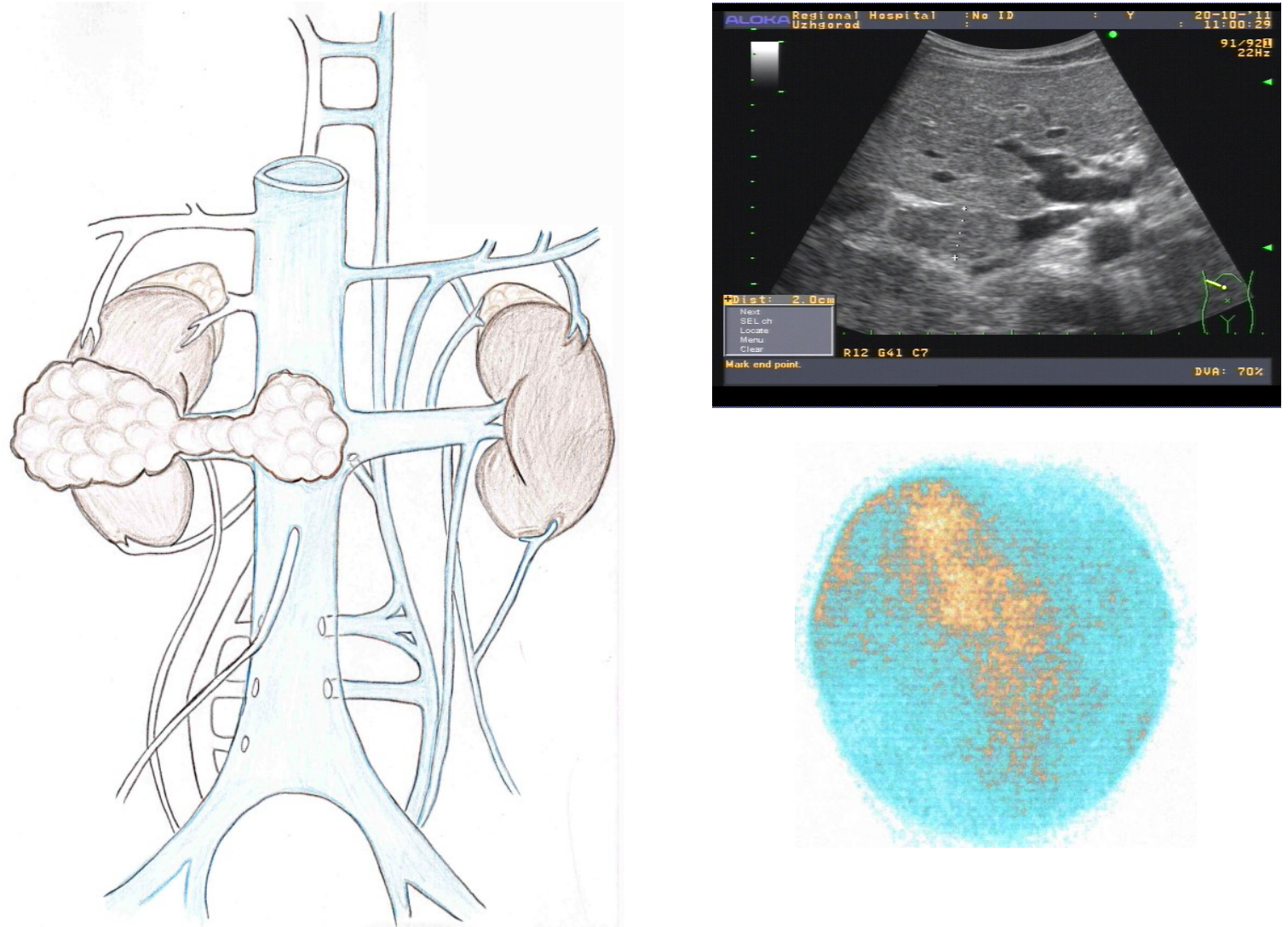

Рис. 2. Схема колатерального венозного відтоку від правої нирки
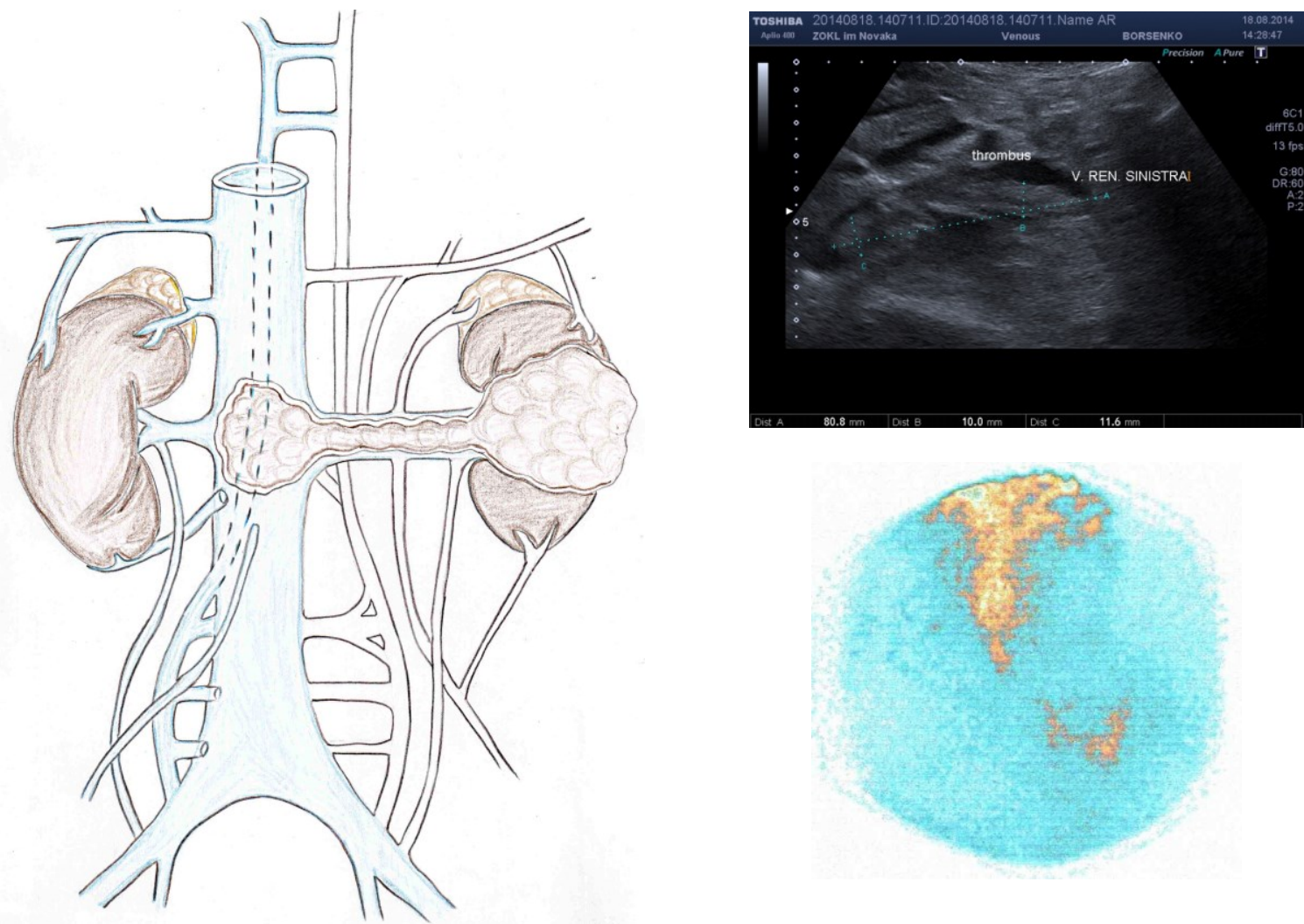

Рис. 3. Схема колатерального венозного відтоку від лівої нирки

При локалізації верхівки тромботичних мас на рівні супрадіафрагмального та інтракардіального відділів нижньої порожнистої вени до сим- птомів ураження внутрішніх органів додаються ознаки правошлуночкової серцевої недостатності. В таких випадках верхівка тромбу може ло- 
калізуватися в порожнині правого передсердя, що може призвести до фатального наслідку. Компенсація колатерального венозного кровоплину відбувається за рахунок міжхребцевих вен, непарної та напівнепарної вен, нижніх та верхніх діафрагмальних вен, портокавальних анастомозів, брахіоцефальних гілок верхньої порожнистої вени.

Таким чином, система нижньої порожнистої вени має широкі анатомічні можливості для компенсації кровоплину при локалізації тромбозу в кавальному венозному колекторі завдяки розвинутій сітці колатерального кровоплину.
Висновки. 1. Запропонований комплексний діагностичний алгоритм довзоляє виявити анатомічні особливості компенсації колатерального кровоплину при тромбозах у кавальному венозному колекторі.

2. Аналіз компенсаторних можливостей колатерального венозного кровоплину дозволяє запропонувати диференційовану тактику профілактики тромбоемболії легеневої артерії.

3. Оцінка анатомічних передумов колатерального кровополину у системі нижньої порожнистої вени дозволяє запобігти виникненню хронічної венозної недостатності.

Інформація про конфлікт інтересів. Конфлікт інтересів при виконанні наукового дослідження та підготовці даної статті відсутній.

Інформація про фінансування. Автори гарантують, що вони не отримували жодних винагород у будь-якій формі, здатних вплинути на результати роботи.

\section{Список використаної літератури}

1. Dubrovskyi AV, Karalkyn A.V, Albytskyi AV, y dr. Funktsyonalnaia anatomyia venoznoho rusla nyzhnykh konechnostei y obosnovanye khyrurhycheskoho vmeshatelstva pry ostrokh flebotrombozakh. Hrudnaia y serdechno-sosudystaia khyrurhyia. 2004;4:34-39. [In Russian].

2. Hull RD, Liang J, Bergqvist D, Yusen RD. Benefit-to-harm ratio of thromboprophylaxis for patients undergoing major orthopaedic surgery. A systematic review. Thromb. Haemost. 2013;24:111-12.

3. Mokri B1, Mariani A, Heit JA, Weaver AL, McGree ME, Martin JR, et al. Incidence and predictors of venous thromboembolism after debulking surgery for epithelial ovarian cancer. Int. J. Gynecol. Cancer. 2013;23 (9);1684-91.

4. Kshettry VR, Rosenbaum BP, Seicean A, Kelly ML, Schiltz NK, Weil RJ. Incidence and risk factors associated with in-hospital venous thromboembolism after aneurysmal subarachnoid hemorrhage. J. Clin. Neurosci. 2013;12: $400-401$.

5. Mirpuri-Mirpuri PG, Alvarez-Cordovés MM, Pérez-Monje A.Venous thromboembolic disease: Presentation of a case. Semergen. 2013;39(5):15-19.

6. Nicolaides AN, Fareed J, Kakkar AK, Comerota AJ, Goldhaber SZ, Hull R,et al. Prevention and treatment of venous thromboembolism. International consensus statement (Guidelines according to scientific evidence). International Angiology. 2006;25:101-61.

7. García-Olivares P, Guerrero JE, Tomey MJ, Hernangómez AM, Stanescu DO. Prevention of venous thromboembolic disease in the critical patient: An assessment of clinical practice in the Community of Madrid. Med Intensiva. 2013;Sep.19:160-65.

8. Tamariz LJ, Eng J, Segal JB, Krishnan JA, Bolger DT, Streiff MB, et al. Usefulness of clinical prediction rules for the diagnosis of venous thromboembolism: a systematic review. American Journal of the Medical Sciences. 2004;117:676-84.

\section{Стаття надійшла до редакції: 12.02.2019 р.}

